\title{
Bidirectional Association between Physical Activity and Dopamine Across Adulthood-A Systematic Review
}

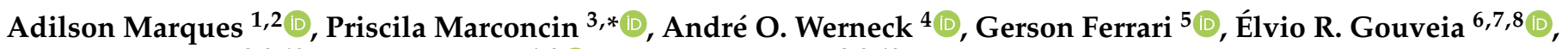 \\ Matthias Kliegel ${ }^{8,9,10}$, Miguel Peralta ${ }^{1,2}$ (D) and Andreas Ihle $8,9,10$
}

1 CIPER, Faculty of Human Kinetics, University of Lisbon, 1499-002 Cruz Quebrada, Portugal; amarques@fmh.ulisboa.pt (A.M.); mperalta@fmh.ulisboa.pt (M.P.)

2 ISAMB, University of Lisbon, 1649-004 Lisbon, Portugal

3 Faculty of Human Kinetics, University of Lisbon, 1649-004 Lisbon, Portugal

4 Center for Epidemiological Research in Nutrition and Health, Department of Nutrition, School of Public Health, University of São Paulo (USP), São Paulo 05508-220, Brazil; andreowerneck@gmail.com

5 Escuela de Ciencias de la Actividad Física, el Deporte y la Salud, Universidad de Santiago de Chile (USACH), Santiago 9170124, Chile; gerson.demoraes@usach.cl

6 Departamento de Educação Física e Desporto, Universidade da Madeira, 9000-390 Funchal, Portugal; erubiog@uma.pt

7 Interactive Technologies Institute, LARSyS, 9020-105 Funchal, Portugal

8 Center for the Interdisciplinary Study of Gerontology and Vulnerability, University of Geneva, 1205 Geneva, Switzerland; matthias.kliegel@unige.ch (M.K.); andreas.ihle@unige.ch (A.I.)

check for updates

Citation: Marques, A.; Marconcin, P.; Werneck, A.O.; Ferrari, G.; Gouveia, É.R.; Kliegel, M.; Peralta, M.; Ihle, A. Bidirectional Association between Physical Activity and Dopamine Across Adulthood-A Systematic Review. Brain Sci. 2021, 11, 829. https://doi.org/10.3390/brainsci 11070829

Academic Editor: Claudia Voelcker-Rehage

Received: 14 May 2021

Accepted: 18 June 2021

Published: 23 June 2021

Publisher's Note: MDPI stays neutral with regard to jurisdictional claims in published maps and institutional affiliations.

Copyright: (c) 2021 by the authors. Licensee MDPI, Basel, Switzerland. This article is an open access article distributed under the terms and conditions of the Creative Commons Attribution (CC BY) license (https:/ / creativecommons.org/licenses/by/ $4.0 /)$.
9 Swiss National Centre of Competence in Research LIVES-Overcoming Vulnerability, Life Course Perspectives, 1015 Lausanne, Switzerland

10 Department of Psychology, University of Geneva, 1205 Geneva, Switzerland

* Correspondence: priscilamarconcin@fmh.ulisboa.pt; Tel.: +351-214149100

\begin{abstract}
Physical activity (PA) may influence the secretion of neurotransmitters and thereby have positive consequences for an individual's vulnerability (i.e., reducing anxiety and depressive symptoms). This systematic review aims to analyse the potential bidirectional effects of exercise on dopamine from young adulthood to old age. The article search was conducted in PubMed, Scopus, and Web of Science in December 2020. The inclusion criteria were longitudinal and experimental study design; outcomes included dopamine and exercise; effect of exercise on dopamine and vice versa; adults; and articles published in English, Portuguese, or Spanish. Fifteen articles were included in the review. We observed robust findings concerning the potential effects of PA on dopamine, which notably seem to be observable across a wide range of participants characteristics (including age and sex), a variety of PA characteristics, and a broad set of methods to analyse dopamine. By contrast, regarding the potential effects of dopamine on PA, findings were mixed across studies. Thus, there are robust effects of physical exercise on dopamine. These findings further strengthen the idea that innovative approaches could include PA interventions for treating and preventing mental disorders. Therefore, it seems that PA is a potential alternative to deal with mental health issues.
\end{abstract}

Keywords: neurotransmitter; brain; physical activity; mental health

\section{Introduction}

Dopamine is a monoamine neurotransmitter that is known to be modulated by physical activity (PA) and exercise [1]. The physiological roles of dopamine were first described in 1957 [2]. Dopamine is synthesized in both the central and peripheral nervous systems, acting as a signalling molecule. Dopamine has essential roles in regulating motor neurons [3], spatial memory function [4], motivation, and reinforcement learning [5]. In addition, dopamine plays a crucial role in maintaining chemical balance within the central nervous system [6]. Concerning vulnerability, an excess or lack of dopamine can cause mental disorders, such as depression [6,7]. 
Dopamine is critical for the motor system [8], and it has a well-established role in motor functioning $[9,10]$. Dopamine synthesis seems to affect the will to practice PA $[11,12]$ and plays an important role in cognitive-motivational reward mechanisms for pursuing a certain behaviour such as PA [13]. This is because dopamine is a key neurotransmitter in the neural system, supporting cognitive control [14]. In turn, successful cognitive control is relevant for continuing PA engagement [15]. This mechanism is emphasized due to the association between the amount of striatal dopamine depletion and motor deficits observed in Parkinson's disease [16].

On the other hand, PA seems to influence the central dopaminergic, noradrenergic, and serotonergic systems [17]. In this regard, it has been observed that an increase in PA seems to result in a corresponding increase in neurotransmitter activity [1,18-20]. PA is known to change the dopamine system in the central nervous system [1], increasing dopamine receptor availability [21]. This association may have positive consequences, such as reducing the severity of symptoms of anxiety, depression, and other mental-related issues [22-24]. Studies in patients with Parkinson's disease also suggest that exercise may provide a preventive and non-pharmaceutical therapeutic approach [25-27]. However, the studies that examined the influence of PA on dopamine were mostly conducted in animals [28-30], and they either used PA as a stress model or compared exercise with other stressors [28].

The mechanism that increases dopaminergic activity during exercise is mostly related to fatigue [31-33]. A decrease in dopamine neurotransmission during PA would hasten the onset of fatigue, while an increase in dopamine neurotransmission might delay the onset of fatigue [31]. Studies that manipulated the increase of dopamine synthesis [34], stimulated extracellular dopamine release [35], inhibited dopamine reuptake [36], or directly activated dopamine neurons and/or dopamine receptors [37] were performed to better understand the role of dopamine in exercise-induced fatigue. Some of these manipulations have been successful in impacting exercise-induced fatigue.

These two different lines of research suggest that there is a bidirectional relationship between the practice of PA and dopamine $[7,11,12,38]$. Yet, so far, the underlying mechanisms are highly debated. Moreover, the existing empirical research investigating this reciprocal association showed high heterogeneity across multiple study parameters and provided mixed and, thus far, inconclusive results [39]. Therefore, to advance the understanding regarding the reciprocal relationship between PA and dopamine synthesis, we conducted a systematic review of the existing evidence concerning the potential PA and exercise effects on dopamine, and vice versa, across adulthood.

\section{Materials and Methods}

\subsection{Search Strategy and Inclusion Criteria}

The review was performed according to the guidelines of the Preferred Reporting Items for Systematic Reviews and Meta-Analyses [40]. We searched for articles that studied the relationship between PA and dopamine synthesis. As the relationship seems to be bidirectional $[7,30,33,34]$, the research was extended to articles that explored the association in either direction. Thus, articles on the relationship between PA and dopamine, published in peer-reviewed journals up to 31 December 2020, were included.

The inclusion criteria of the articles were (a) longitudinal and experimental study design (study design criterion); (b) outcomes included dopamine and PA (outcome measure criterion); (c) effect of PA on dopamine and vice versa (relationship criterion); (d) adults (participants criterion); (e) articles published in English, Portuguese, or Spanish, regardless of the date of publication (language criterion). Studies were excluded from analysis if they were cross-sectional, did not have PA or dopamine synthesis as the outcome, and if participants were under 18 years of age.

In December 2020, a search was performed for articles in PubMed and Scopus databases and the meta-search engine Web of Science. The search was performed using the following terms: ("physical activity" OR exercise * OR train * OR sport *) AND 
(dopamine OR dihydroxyphenethylamine OR oxytyramine OR 3-hydroxytyramine) AND ("mental health" OR "mental disorder *" OR "mental problem *" OR "cognitive health" OR "cognitive disorder *" OR "cognitive problem *" OR depressi * OR anxiety OR dementia). Two authors screened titles and abstracts to identify articles that met the inclusion criteria. Two authors read the articles and decided whether they should be included in the analysis or excluded. The inclusion decision was consensual and in cases of disagreement, the decision was made by mutual agreement. A reverse search was conducted to screen publications that cited the identified studies. We also checked the reference lists of identified studies for further potential studies to include.

\subsection{Data Extraction}

From the articles, the author name(s), year of publication, study design, sample characteristics, country, method of the outcome variables, and main results were extracted. The extraction was carried out by one author, and coding was verified by two other authors.

\subsection{Quality Assessment (Risk of Bias)}

We used the Quality Assessment Tool for Quantitative Studies of the Effective Public Health Practice Project to assess the methodological quality and risk of bias of each study [41]. The study received a final rating as "strong", "moderate", or "weak". The scale evaluated different aspects of the research: (A) selection bias, (B) study design, (C) confounders, (D) blinding, (E) data collection methods, (F) withdrawals and dropouts, $(\mathrm{G})$ intervention integrity, and $(\mathrm{H})$ analysis. Each item received a final score of "strong", "moderate", or "weak", according to the recommendations of the scale. Each study received a final rating as "strong" (when it received no "weak" ratings), "moderate" (when the study received one "weak" rating), or "weak" (two or more "weak" ratings). As we included clinical trials and cohort studies, we did not consider the item of selection bias for the clinical trials, and we did not consider the items of blinding and intervention integrity for cohort studies. The quality assessment is presented in Table 1. The majority of the papers were classified as "weak", indicating a considerable risk of bias. There were only two studies classified as "moderate" [42,43], and one classified as "strong" [44]. The lack of adjustment for potential confounders in the analyses and the lack of blinding were the major sources of bias in the articles.

\subsection{Synthesis of Results}

Among the articles, there was great heterogeneity in the different parameters analysed. This made it impossible to carry out a meta-analysis. To facilitate the interpretation of the results, the data of each article were collected and presented consistently. As the articles presented relationships in different directions, a table was created for articles that analysed the effect of PA on dopamine, and another table was created for articles that analysed the effect of dopamine on PA. 
Table 1. Quality assessment.

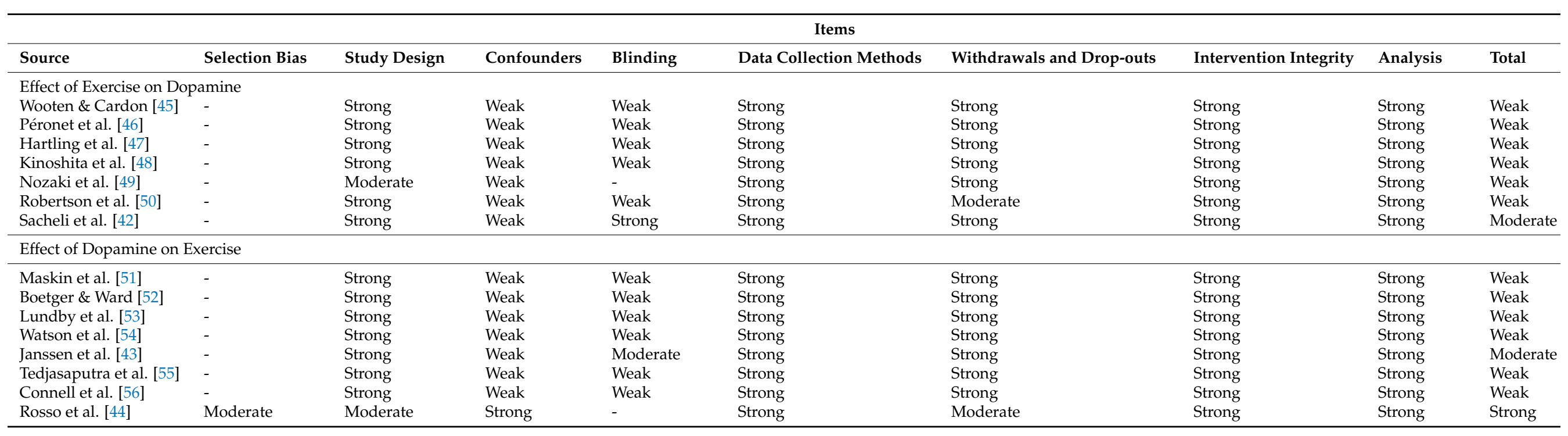




\section{Results}

\subsection{Literature Search}

From the database search, 940 records were identified. Among those 940 records, 542 were duplicates and were eliminated. The remaining 398 records were analysed based on the title and abstract for potential inclusion in the subsequent full read. At this stage, 334 records were eliminated. The full text of 64 records was evaluated, and 47 were excluded for the following reasons: different outcomes $(n=38)$, the article was inaccessible $(n=6)$, the study design was not experimental or longitudinal $(n=3)$, the article was classified as a method description article $(n=1)$, or the article was a review $(n=1)$. Therefore, 15 articles were included in the systematic review. From the 15 included studies, 7 investigated the effect of PA on dopamine, while the other 8 examined the effect of dopamine on PA. The flow diagram of the study search is presented in Figure 1.

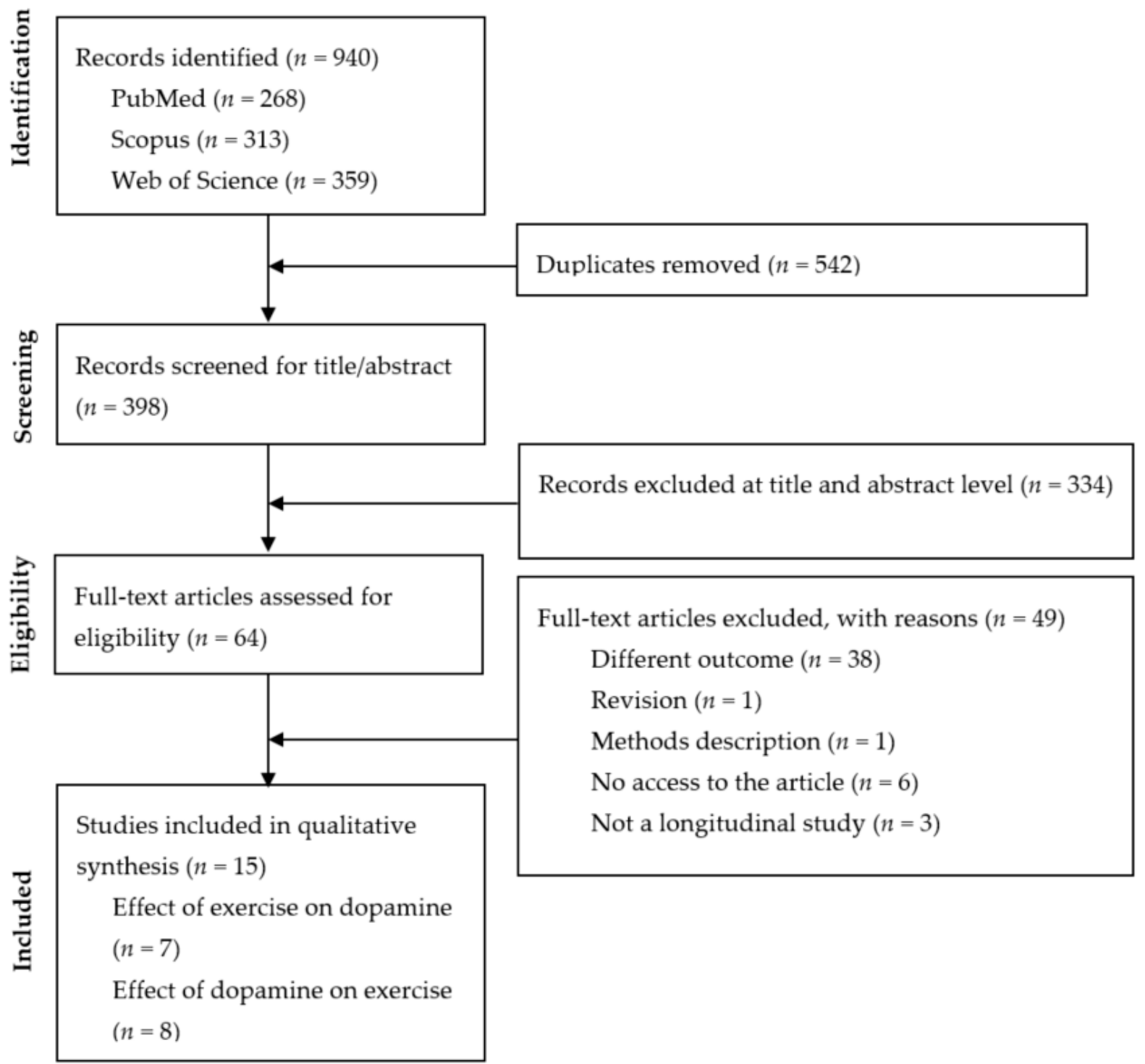

Figure 1. Flow diagram of study selection.

\subsection{Effect of Exercise on Dopamine}

The characteristics and main findings of the seven studies analysing the effect of PA (exposure) on dopamine (outcome) are presented in Table 2. 
Table 2. Characteristics and the main results of studies analysing the effect of exercise on dopamine.

\begin{tabular}{|c|c|c|c|c|}
\hline Source & $\begin{array}{l}\text { Study Design, Sample } \\
\text { Characteristics (n, Sex, Age } \\
\text { in Years), Country }\end{array}$ & $\begin{array}{l}\text { Outcome Measures } \\
\text { (Dopamine) }\end{array}$ & $\begin{array}{l}\text { Exercise Training } \\
\text { Protocol or Interventions }\end{array}$ & Main Findings \\
\hline Wooten \& Cardon [45] & $\begin{array}{l}\text { Experimental study, } 6 \\
\text { participants ( } 3 \text { men, } 3 \text { women), } \\
\text { aged } 18 \text { to } 20 \text {, USA. }\end{array}$ & $\begin{array}{l}\text { Blood sample } \\
\text { measurements of } \\
\text { DBH activity. }\end{array}$ & $\begin{array}{l}\text { The cold pressor test } \\
\text { involved immersion of the } \\
\text { hand in ice water for } 3 \\
\text { min. The exercise was a } \\
\text { two-step test ( } 21-\mathrm{cm} \text { steps) } \\
\text { performed at the fastest } \\
\text { tolerable rate. }\end{array}$ & $\begin{array}{l}\text { Cold pressor test and } \\
\text { exercise resulted in small } \\
\text { but significant elevations } \\
\text { of plasma DBH activity. } \\
\text { No significant change } \\
\text { occurred during tilting. }\end{array}$ \\
\hline Péronet et al. [46] & $\begin{array}{l}\text { Experimental study, } 7 \text { football } \\
\text { players, male, mean age } \\
19 \pm 1.0, \text { Canada. }\end{array}$ & $\begin{array}{l}\text { Blood samples were taken } \\
\text { during the last min of each } \\
\text { condition for } \\
\text { measurements of } \\
\text { DBH activity. }\end{array}$ & $\begin{array}{l}\text { Supine test for } 20 \mathrm{~min} \text {, } \\
3 \text { min of handgrip exercise, } \\
\text { and } 10 \text { min in a standing } \\
\text { position at end of a } \\
\text { supramaximal cycle } \\
\text { ergometer test. }\end{array}$ & $\begin{array}{l}\text { DBH activity increased } \\
\text { above resting level during } \\
\text { supramaximal } \\
\text { dynamic exercise. }\end{array}$ \\
\hline Hartling et al. [47] & $\begin{array}{l}\text { Experimental study, } 6 \text { males, } \\
\text { mean age } 25.0 \pm 4.0 \text {, Denmark. }\end{array}$ & $\begin{array}{l}\text { Catecholamines were } \\
\text { collected from the brachial } \\
\text { artery and the deep vein. }\end{array}$ & $\begin{array}{l}\text { Dynamic forearm exercise, } \\
\text { rate of } \\
50 \text { contractions / min on a } \\
\text { spring-loaded hand } \\
\text { ergometer. Three min } \\
\text { bouts of exercise were } \\
\text { performed with } 15 \text { min } \\
\text { intervals until complete } \\
\text { exhaustion. }\end{array}$ & $\begin{array}{l}\text { Adrenaline and } \\
\text { noradrenaline increased. } \\
\text { Dopamine concentrations } \\
\text { did not change. }\end{array}$ \\
\hline Kinoshita et al. [48] & $\begin{array}{l}\text { Experimental study, } 12 \\
\text { hypertension patients ( } 4 \text { men, } \\
8 \text { women), mean age } \\
51.7 \pm 2.3 \text {, Japan. }\end{array}$ & $\begin{array}{l}\text { 24-h urine and fasting } \\
\text { blood samples were } \\
\text { collected at weeks } 0,1,2,4 \text {, } \\
7 \text {, and } 10 \text { of exercise. }\end{array}$ & $\begin{array}{l}\text { Bicycle ergometer } \\
\text { exercises, } 3 \text { times per week } \\
\text { for } 10 \text { weeks. }\end{array}$ & $\begin{array}{l}\text { Urine dopamine increased } \\
\text { significantly in the } 4 \text { th } \\
\text { week, from } \\
386 \pm 9.4 \mu \mathrm{g} / \text { day at week } \\
0 \text { to } 524 \pm 6.3 \mu \mathrm{g} / \text { day. }\end{array}$ \\
\hline Nozaki et al. [49] & $\begin{array}{l}\text { Retrospective observational } \\
\text { study, } 12 \text { Parkinson's disease } \\
\text { patients ( } 6 \text { men, } 6 \text { women), } \\
\text { mean age } 64.9 \pm 7.8 \text {, Japan. }\end{array}$ & $\begin{array}{l}\text { Tomography scans during } \\
\text { right-foot movement in } \\
\text { DBS-off and DBS-on } \\
\text { conditions. }\end{array}$ & $\begin{array}{l}\text { Right-foot sequential } \\
\text { extension/flexion } \\
\text { movements at } \\
\text { participant's own pace } \\
\text { (close to } 0.5 \mathrm{~Hz} \text { ). }\end{array}$ & $\begin{array}{l}\text { Lack of dopamine release } \\
\text { in the putamen and } \\
\text { significant dopamine } \\
\text { release in the } \\
\text { ventromedial striatum by } \\
\text { STN-DBS during exercise. }\end{array}$ \\
\hline Robertson et al. [50] & $\begin{array}{l}\text { Retrospective observational } \\
\text { study, } 19 \text { methamphetamine- } \\
\text { dependent participants } \\
\text { (11 men, } 8 \text { women), mean age } \\
29.8 \pm 5.9 \text {, USA. }\end{array}$ & $\begin{array}{l}\text { D2/D3 BPND was } \\
\text { determined using }\left({ }^{18} \mathrm{~F}\right) \\
\text { Fallypride. }\end{array}$ & $\begin{array}{l}\text { Exercise training group } \\
(\text { EX): } 1 \mathrm{~h} \text { individualized } \\
\text { exercise sessions } \\
\text { (resistance training) } \\
3 \text { days/week for } 8 \text { weeks. } \\
\text { Education control group: } \\
\text { health education sessions, } \\
1 \text { h, } 3 \text { times/week for } \\
8 \text { weeks. }\end{array}$ & $\begin{array}{l}\text { EX showed a significant } \\
\text { increase in striatal D2/D3 } \\
\text { BPND, no changes in } \\
\text { D2/D3 BPND in } \\
\text { extrastriatal regions. }\end{array}$ \\
\hline Sacheli et al. [42] & $\begin{array}{l}\text { RCT, } 20 \text { participants with mild } \\
\text { to moderate (Hoehn \& Yahr } \\
\text { stages I-III) idiopathic } \\
\text { Parkinson's disease, ( } 13 \text { men, } \\
7 \text { women), mean age } \\
66.7 \pm 5.9 \text {, Canada. }\end{array}$ & $\begin{array}{l}\left({ }^{11} \mathrm{C}\right) \text { raclopride positron } \\
\text { emission tomography } \\
\text { scans to determine the } \\
\text { effect of aerobic exercise } \\
\text { on the repetitive } \\
\text { transcranial magnetic } \\
\text { stimulation-evoked } \\
\text { release of endogenous } \\
\text { dopamine in the dorsal } \\
\text { striatum. }\end{array}$ & $\begin{array}{l}\text { Aerobic exercise: } \\
40-60 \text { min of cycling. } \\
\text { Control: series of seated } \\
\text { and standing stretches and } \\
\text { low-impact exercises. } \\
\text { Both: } 3 \text { times per week for } \\
3 \text { months ( } 36 \text { sessions). }\end{array}$ & $\begin{array}{l}\text { The aerobic group } \\
\text { demonstrated increased } \\
\text { repetitive transcranial } \\
\text { magnetic } \\
\text { stimulation-evoked } \\
\text { dopamine release in the } \\
\text { caudate nucleus. }\end{array}$ \\
\hline
\end{tabular}

Abbreviations: D2/D3 BPND, dopamine D2/D3 receptor availability; DAT, dopamine transporter availability; DBH, dopamine- 3 hydroxylase; DBS, deep brain stimulation; RCT, randomized controlled trial; STN, subthalamic nucleus.

\subsubsection{Participants Characteristics}

The number of participants in the seven included studies ranged from $6[45,47]$ to 20 [42]. Regarding sex, five studies had a mixed (men and women) sample [42,45,48-50], while two studies had a sample only including men [46,47]. Concerning age, in four studies, the sample was composed of young adults (mean age ranged from 18 to 30 years across studies) $[45-47,50]$. In the other three studies, the sample was composed of middle-aged and/or older adults (mean age ranged from $51.7 \pm 2.3$ to $66.7 \pm 5.9$ years across studies) [42,49]. Finally, four studies were performed in special clinical popula-tions, one among hyperten- 
sive individuals [48] two among individuals with Parkin-son's disease [42,49], and the last one among individuals addicted to methampheta-mine [50].

\subsubsection{Exercise Training Protocols and Interventions}

Each exercise training protocol and intervention was unique among the seven included studies. Participants in three studies performed exercise interventions: participants in one study performed bicycle ergometer exercises three times a week for a total of 10 weeks [48], participants in another performed 60-min sessions of individualized resistance training three times a week for a total of eight weeks [50], and participants in the most recent study performed 40-60-min sessions of aerobic cycling three times a week for a total of eight weeks [42]. Three studies used maximal and submaximal exer-cise training protocols, including a two-step test [45], a combined supine followed by a cycle ergometer test [46], and a forearm with hand ergometer test [47]. In the remain-ing study, individuals with Parkinson's disease performed a right-foot sequential ex-tension/flexion protocol at each participant's pace [49].

\subsubsection{Outcome Measures}

To examine dopamine, three studies collected blood samples, of which two investigated dopamine- $\$$-hydroxylase $[45,46]$, and one analysed catecholamine (adrenaline, noradrenaline, and dopamine) [47]. Two studies used tomography scans; one per-formed scans during exercise on the dopaminergic system [49] and the other one $\left({ }^{11} \mathrm{C}\right)$ used raclopride positron emission tomography scans to determine the effect of aerobic exercise on the repetitive transcranial magnetic stimulation-evoked release of endog-enous dopamine in the dorsal striatum [42]. One study collected urine samples [48]. Lastly, one study used a radioligand technique to determine dopamine D2/D3 receptor availability using $\left({ }^{18} \mathrm{~F}\right)$ fallypride [50].

\subsubsection{Main Findings}

Overall, six studies found a positive effect of physical exercise on dopamine and one study found no effect. Regarding the exercise intervention studies, one study showed that urine dopamine significantly increased at four weeks [48], another pre-sented an increase in striatal dopamine D2/D3 receptor availability but no changes in the extrastriatal regions [50], and one found an increased repetitive transcranial mag-netic stimulationevoked dopamine release in the caudate nucleus [42]. Among the remaining four studies, two found that exercise increased blood plasma dopamine [45,46], and the others observed a significant dopamine release in the ventromedial striatum and a lack of dopamine release in the putamen during exercise [49]. However, one study did not observe significant changes in dopamine concentration after exercise [47].

\subsection{Effect of Dopamine on PA}

The characteristics and main findings of the eight studies analysing the effect of dopamine (exposure) on PA (outcome) are presented in Table 3.

Table 3. Characteristics and the main results of studies analysing the effect of dopamine on physical activity and exercise.

\begin{tabular}{|c|c|c|c|c|}
\hline Source & $\begin{array}{l}\text { Study Design, Sample } \\
\text { Characteristics (n, Sex, } \\
\text { Age in Years), Country }\end{array}$ & Outcome Measures (PA) & Dopamine-Related Exposure & Main Findings \\
\hline Maskin et al. [51] & $\begin{array}{l}\text { Experimental study, } \\
13 \text { patients ( } 9 \text { men, } \\
4 \text { women) with severe } \\
\text { chronic congestive heart } \\
\text { failure, mean age } 59 \\
\text { (range } 48-72 \text { ), USA. }\end{array}$ & $\begin{array}{l}\text { Bicycle ergometer. The } \\
\text { initial workload was } 25 \mathrm{~W} \\
\text { for } 3 \text { min, and this load } \\
\text { was increased every } 3 \text { min } \\
\text { by } 12.5 \mathrm{~W} \text { until } \\
\text { exhaustion. }\end{array}$ & $\begin{array}{l}\text { Drug exposure: Dopamine was } \\
\text { infused at an initial rate of } \\
2 \mu \mathrm{g} / \mathrm{kg} / \mathrm{min} \text { for } 15 \mathrm{~min}\end{array}$ & $\begin{array}{l}\text { DA exerted a slight } \\
\text { chronotropic effect but } \\
\text { did not improve } \\
\text { ventricular performance } \\
\text { during maximal } \\
\text { exercise. }\end{array}$ \\
\hline
\end{tabular}


Table 3. Cont.

\begin{tabular}{|c|c|c|c|c|}
\hline Source & $\begin{array}{l}\text { Study Design, Sample } \\
\text { Characteristics (n, Sex, } \\
\text { Age in Years), Country }\end{array}$ & Outcome Measures (PA) & Dopamine-Related Exposure & Main Findings \\
\hline Boetger \& Ward [52] & $\begin{array}{l}\text { Controlled trial, } 5 \text { healthy } \\
\text { males, USA. }\end{array}$ & $\begin{array}{l}\text { A series of square-wave } \\
\text { sub-anaerobic work-rate } \\
\text { step tests on a bicycle } \\
\text { ergometer was } \\
\text { administered to each } \\
\text { participant on } 2 \text { days. }\end{array}$ & $\begin{array}{l}\text { Drug exposure: } 3 \mu \mathrm{g} / \mathrm{kg} / \mathrm{min} \text { of } \\
\text { dopamine at least } 10 \mathrm{~min} \text { before } \\
\text { the dopamine test to ensure } \\
\text { equilibration }\end{array}$ & $\begin{array}{l}\text { Steady-state } \mathrm{VE}, \mathrm{VCO}_{2} \text {. } \\
\text { And } \mathrm{VO}_{2} \text { were } \\
\text { unchanged by } \\
\text { dopamine infusion, both } \\
\text { during unloaded } \\
\text { pedalling and at the } \\
\text { heavier workload. }\end{array}$ \\
\hline Lundby et al. [53] & $\begin{array}{l}\text { RCT, } 12 \text { sea-level natives } \\
\text { ( } 5 \text { women, } 7 \text { men), aged } \\
26 \pm 1.4 \text {, Denmark, } \\
\text { Switzerland, and Italy. }\end{array}$ & $\begin{array}{l}\text { Two consecutive maximal } \\
\text { exercise bouts, separated } \\
\text { by an interval of } 1 \mathrm{~h} \text {, were } \\
\text { performed on } 4 \text { separate } \\
\text { occasions: at sea level and } \\
\text { on day } 1 \text { (HA1, } 24 \mathrm{~h} \text { after } \\
\text { arrival), day } 3 \text { (HA3), and } \\
\text { day } 5 \text { (HA5) at high } \\
\text { altitude. Five-minute } \\
\text { warm-up at } 120 \mathrm{~W} \text { on a } \\
\text { Monark } 848 \text { cycle } \\
\text { ergometer and maximal } \\
\text { exercise test. The protocol } \\
\text { was designed to exhaust } \\
\text { the participants within } \\
3-5 \text { min. } \\
\text { Constant cycle exercise for } \\
60 \text { min at a workload }\end{array}$ & $\begin{array}{l}\text { Drug exposure: } 30 \mathrm{mg} \text { of } \\
\text { domperidone (orally) }\end{array}$ & $\begin{array}{l}\text { Hypoxic exercise in } \\
\text { humans activated } \\
\text { D2-receptors, resulting } \\
\text { in a decrease in } \\
\text { circulating levels of } \\
\text { noradrenaline. } \\
\text { However, dopamine } \\
\text { D2-receptors were not } \\
\text { involved in the } \\
\text { hypoxia-induced } \\
\text { decrease at the maximal } \\
\text { heart rate. }\end{array}$ \\
\hline Watson et al. [54] & $\begin{array}{l}\text { Experimental randomized } \\
\text { double-blind study, } \\
9 \text { healthy males, cyclists } \\
\text { or triathletes, aged } \\
22.7 \pm 4.3, \text { Belgium. }\end{array}$ & $\begin{array}{l}\text { corresponding to } 55 \% \\
W_{\text {max }} \text {, followed by a TT to } \\
\text { measure performance. The } \\
\text { TT required the } \\
\text { participants to complete a } \\
\text { predetermined amount of } \\
\text { work equal to } 30 \text { min at } \\
75 \% W_{\max } \text { as quickly } \\
\text { as possible. }\end{array}$ & $\begin{array}{l}\text { Drug exposure: Placebo or } \\
2 \times 300 \mathrm{mg} \text { bupropion }\end{array}$ & $\begin{array}{l}\text { Performance in warm } \\
\text { conditions is enhanced } \\
\text { by acute administration } \\
\text { of a dual dopamine/ } \\
\text { noradrenaline reuptake } \\
\text { inhibitor. }\end{array}$ \\
\hline Janssen et al. [43] & $\begin{array}{l}\text { Prospective } \\
\text { placebo-controlled } \\
\text { randomized study, } \\
13 \text { healthy males, aged } \\
23 \pm 3 \text {, Belgium. }\end{array}$ & $\begin{array}{l}\text { Each participant } \\
\text { underwent a } \\
\text { physician-supervised } \\
\text { standard incremental } \\
\text { CPET until the } \\
\text { symptom-limited } \\
\text { maximum. The work rate } \\
\text { was increased by } 30 \mathrm{~W} \text { per } \\
\text { minute after } 1 \mathrm{~min} \\
\text { pedalling at } 0 \mathrm{~W} \text {. }\end{array}$ & $\begin{array}{l}\text { Drug exposure: Dopamine } \\
(3 \mu \mathrm{g} / \mathrm{min} / \mathrm{kg}) \text { or placebo } \\
\text { infusion }(0.9 \% \mathrm{NaCl})\end{array}$ & $\begin{array}{l}\text { Inhibition of peripheral } \\
\text { chemoreflex function } \\
\text { with dopamine } \\
\text { decreased the } \mathrm{V}_{\mathrm{E}} / \mathrm{V}_{\mathrm{CO} 2} \\
\text { slope during dynamic } \\
\text { exercise, with no change } \\
\text { in aerobic exercise } \\
\text { capacity. }\end{array}$ \\
\hline Tedjasaputra et al. [55] & $\begin{array}{l}\text { Experimental study with } \\
\text { placebo control, } 12 \text { healthy } \\
\text { males, aged } 25 \pm 6, \\
\text { Canada. }\end{array}$ & $\begin{array}{l}\text { Two incremental staged } \\
\text { cycling exercise sessions. } \\
\text { The initial power output } \\
\text { was set to } 50 \mathrm{~W} \text {, and the } \\
\text { power output was } \\
\text { increased by } 25 \mathrm{~W} \text { every } \\
2 \text { min until the ventilatory } \\
\text { threshold was reached. }\end{array}$ & $\begin{array}{l}\text { Drug exposure: Placebo or a DA } \\
\text { receptor blocker } \\
\text { (metoclopramide } 20 \mathrm{mg} \text { ) }\end{array}$ & $\begin{array}{l}\text { DA blockade did not } \\
\text { change } \mathrm{O}_{2} \text { consumption, } \\
\mathrm{CO}_{2} \text { production, or } \\
\text { respiratory exchange } \\
\text { ratio at different exercise } \\
\text { intensities. DA blockade } \\
\text { decreased maximal } \\
\text { cardiac output, VO } 2_{\text {max, }} \\
\text { and TTE. Blocking DA } \\
\text { receptors appeared to be } \\
\text { detrimental to exercise } \\
\text { performance. }\end{array}$ \\
\hline Connell et al. [56] & $\begin{array}{l}\text { Double-blind, } \\
\text { placebo-controlled, } \\
\text { repeated-measures } \\
\text { randomized crossover } \\
\text { study, } 12 \text { trained cyclists } \\
\text { ( } 7 \text { women, } 5 \text { men), mean } \\
\text { age } 25 \text { (19-45), } \\
\text { New Zealand. }\end{array}$ & $\begin{array}{l}\text { Three experimental trials } \\
\text { involving } 180 \text { min of } \\
\text { continuous cycling at a } \\
\text { work rate equivalent to } \\
60 \% \text { of maximal aerobic } \\
\text { capacity. A minimum of } \\
5 \mathrm{~d} \text { between crossover } \\
\text { phases was enforced. }\end{array}$ & $\begin{array}{l}\text { Drug exposure: DRI ( } 40 \mathrm{mg} \\
\text { methylphenidate), NRI ( } 8 \mathrm{mg} \\
\text { reboxetine), and placebo }\end{array}$ & $\begin{array}{l}\text { DA reuptake inhibition } \\
\text { and norepinephrine } \\
\text { reuptake inhibition } \\
\text { prevented } \\
\text { fatigue-related } \\
\text { decrements in the peak } \\
\text { velocity of prosaccades. }\end{array}$ \\
\hline
\end{tabular}


Table 3. Cont

\begin{tabular}{|c|c|c|c|c|}
\hline Source & $\begin{array}{l}\text { Study Design, Sample } \\
\text { Characteristics (n, Sex, } \\
\text { Age in Years), Country }\end{array}$ & Outcome Measures (PA) & Dopamine-Related Exposure & Main Findings \\
\hline Rosso et al. [44] & $\begin{array}{l}\text { Cohort, } 1635 \text { sedentary } \\
\text { adults at risk for disability, } \\
65.9 \% \text { women, aged } \\
78 \pm 5.2, \text { USA. }\end{array}$ & $\begin{array}{l}\text { PA was calculated from } \\
\text { accelerometry (min/d) at } \\
\text { baseline, } 6,12 \text {, and } \\
24 \text { months. PA versus } \\
\text { health education for an } \\
\text { average of } 2.6 \text { years. PA } \\
\text { intervention consisted of } \\
\text { walking (goal of } \\
150 \text { min/week), strength, } \\
\text { flexibility, and balance } \\
\text { training. }\end{array}$ & $\begin{array}{l}\text { No drug exposure: Single } \\
\text { nucleotide polymorphisms of } \\
\text { dopamine-related genes } \\
\text { (dopamine receptor (DR) D1, } \\
\text { DRD2, DRD3, and } \\
\text { catechol-O-methyltransferase) }\end{array}$ & $\begin{array}{l}\text { Higher dopamine } \\
\text { signalling may support } \\
\text { changes in PA during } \\
\text { an intervention. }\end{array}$ \\
\hline
\end{tabular}

Abbreviations: DA, dopamine; VE, breath-by-breath ventilation; $\mathrm{VCO}_{2}, \mathrm{CO}_{2}$ production; $\mathrm{VO}_{2}, \mathrm{O}_{2}$ consumption; $\mathrm{HA} 1, \mathrm{HA} 3$, and $\mathrm{HA} 5$, days 1, 3 and 5 respectively at high altitude; ACTH, adrenocorticotropic hormone; CPET, cardiopulmonary exercise testing; DR, dopamine receptor; PA, physical activity; SNPs, single nucleotide polymorphisms; TT, trial time; TTE, time to exhaustion; MVPA, minutes of moderate-to-vigorous physical activity.

\subsubsection{Participant Characteristics}

Among the eight included studies, the number of participants ranged from 5 [52] to 1635 [44]. In four studies, the sample was exclusively composed of men [43,52,54,55], while the remaining six studies had samples composed of both men and women [51,56]. Concerning age, most studies were with young adults (mean range between 22 and 26 years). In three studies, participants had a mean age between 59 and 78 years [44,51], and one study did not reveal participants' ages [52]. Of the eight studies, four studies were performed with special populations: two in athletes [54,56]; one among individuals with severe chronic congestive heart failure [51]; and one in sedentary individuals at risk of disability [44].

\subsubsection{Dopamine-Related Exposure}

Seven studies used drug exposure, while one study analysed dopamine without exposure to drugs. Regarding the studies that used drug exposure, in three studies, dopamine was directly administered to the participants at different doses, $2 \mu \mathrm{g} / \mathrm{kg} / \mathrm{min}$ [51] and $3 \mu \mathrm{g} / \mathrm{kg} / \mathrm{min}[43,52]$. The other four studies administered dopamine inhibitor drugs, including, metoclopramide (20 mg) [55], domperidone (30 mg) [53], bupropion (2 × $300 \mathrm{mg}$ ) [54], methylphenidate $(40 \mathrm{mg})$ and reboxetine $(8 \mathrm{mg})$ [56]. The study without exposure to drugs analysed single nucleotide polymorphisms of dopamine-related genes [44].

\subsubsection{Outcome Measures}

The seven studies that used drug exposure also assessed PA by performing submaximal or maximal cycle exercise protocols [43,51-56]. The remaining study assessed habitual PA by accelerometry [44].

\subsubsection{Main Findings}

Concerning the three studies that directly administered dopamine, no significant effects were observed in the cardiac system or aerobic exercise capacity $[43,51,52]$. The studies that administrated dopamine inhibitor drugs found contradicting results. On the one hand, two studies observed that the dopamine inhibitor drugs had a positive effect on performance [54] and fatigue-related decrements in the peak velocity of pro-saccades [56]. On the other hand, one study showed that blocking dopamine receptors appeared to be detrimental to exercise performance [55]. In another study, it was found that dopamine D2-receptors were not involved in the hypoxia-induced decrease at the maximal heart rate [53]. The study that did not administer any drugs suggested a positive association between the expression of dopamine-related genes and habitual PA [44]. 


\section{Discussion}

We systematically reviewed the existing research on reviewed the existing re-search on the bidirectional relationship between exercise or PA and dopamine. Regarding the effects of exercise on dopamine, the majority of included studies (6 out of 7) reported potential effects of exercise on dopamine [42,45,46,48,50]. Exercise resulted in increased urine dopamine [48], increased striatal dopamine D2/D3 receptor availability [50], increased dopamine release in the caudate nucleus [42], dopamine release in the ventromedial striatum [26], and increased blood plasma dopamine [45,46]. Only one study did not observe significant changes in dopamine concentration after exercise [47]. Findings of the potential effects of dopamine on PA were mixed across studies. No significant effect was observed on the cardiac system or aerobic exercise capacity in three studies that administered dopamine $[43,51,52]$. Contradictory results were found in studies that administrated dopamine inhibitor drugs, with dopamine inhibitor drugs, having a positive effect on perfor-mance [54] and fatigue-related decrements in the peak velocity of prosaccades [56]. Nonetheless, blocking dopamine receptors seems to be detrimental to exercise performance [55], and a significant positive association between the expression of dopa-mine-related genes and habitual PA was observed [44].

The mental health benefits of PA are well documented [57]. Regular PA and exercise contribute to improved mental health through improving cognition [58-60], increasing BDNF levels in the brain [61], and brain plasticity [59]. Furthermore, people who are more physically active and have better fitness levels are less likely to have mental illnesses such as depression and anxiety [62-64]. From the results of this systematic review, it is possible to observe that exercise has a positive and significant effect on dopamine synthesis. It was observed that six out of seven studies reported effects of exercise on dopamine $[42,45,46,48,50]$, which means that exercise can have a positive impact on mental health. For this reason, PA and exercise are, in some cases, effective behaviours for the prevention of mental illness and have a positive effect on the treatment of mental health problems [57]. Therefore, treatment guidelines for mental health should emphasize exercise [65]. To determine how exercise can benefit mental health, it is important to study its link to chemicals associated with stress and mental health $[22,66]$. One theory is that PA and exercise trigger the release of dopamine, which can improve mood [60]. It is important to emphasize that dopamine is a monoamine that regulates, and experiences regulatory influence from, the other two major monoamine neurotransmitters, noradrenaline and serotonin. This means that the monoamine system mediates the exercise-induced improvement of various brain functions [60].

As exercise is a complex behaviour (i.e., its frequency, duration, intensity, context, and other variables associated with its performance have to be considered), there could be different results among the analysed studies because studies differed substantially regarding the characteristics of the respective exercise. However, the majority of the studies spoke for the possibility that the relationship of exercise influencing dopamine may be observable across a variety of exercise characteristics $[42,45,46,48-50]$. These results reinforce the idea that the importance is more in the behaviour itself than in the way the PA behaviour is performed. For curing mental health issues, of which low dopamine synthesis is one of the main causes [6,7], these results are encouraging because innovative perspectives could include the prescription of exercise as a treatment.

It is well known that dopamine has a role in motor functioning $[9,10]$, which may influence a willingness for PA [11,12]. Studies with animals have shown that blocking dopamine receptors results in less engagement in exercise voluntarily [67]. Thus, it can be speculated that in humans a central component might control PA levels as part of a biological regulation scheme, such as dopaminergic function. This hypothesis is based on the fact that the dopaminergic system has implications in many brain functions, including: rewards, motivation, learning, stimuli response, and movement [68]. As a result, it is suggested that dopaminergic signalling acts in a dependent and independent way in the regulation of PA. Nonetheless, findings of the potential effects of dopamine on PA were 
unclear. No significant effect was observed on the cardiac system or aerobic exercise capacity in three studies that administered dopamine [43,51,52]. Contradictory results were found in the studies that administrated dopamine inhibitor drugs, with dopamine inhibitor drugs having a positive effect on performance [54] and fatigue-related decrements in the peak velocity of prosaccades [56]. Blocking dopamine receptors in one study seemed to be detrimental for physical exercise performance [55], while in another study it was found that dopamine D2-receptors were not involved in the hypoxia-induced decrease in the maximal heart rate [53]. A significant positive association between the expression of dopaminerelated genes and habitual PA was observed [44]. Thus, only the study examining the link between dopamine without exposure to drugs and real-life PA was able to demonstrate a coherent positive influence of dopamine on PA, regardless of the differences in participants' characteristics. One may argue that the non-significant studies may have a relatively small sample [43,51-53], but they were comparable in size to other studies observing significant relationships [54-56]. Thus, from these results, it is not possible to determine that there is a relationship. More studies are needed to clarify whether the levels of dopamine in the brain influence the willingness to practice PA and, consequently, the levels of PA.

It is important to mention methodological details that systematically varied across the eight studies that analysed the effect of dopamine on PA. The seven studies that used drug exposure assessed PA by performing submaximal or maximal cycle exercise protocols and reported either non-significant or mixed results [43,51-56]. Notably, the remaining study, which analysed dopamine without exposure to drugs, assessed habitual PA using accelerometers [44]. This suggests that the particular PA assessment may constitute an important methodological factor for the potential effects of dopamine on PA. Similarly, the findings suggest that laboratory drug administration can differ from neutral conditions among people with different gene expression. Therefore, it is plausible to infer that acute dopamine release may not be determinant for exercise performance, but a constantly greater release of dopamine through determined genetic expressions may be associated with higher levels of habitual PA in the long term. However, more studies are still needed to investigate the association in neutral conditions.

The current systematic review findings should be interpreted in light of some limitations. Although study quality was assessed, studies were not weighted or ranked, nor were any removed from the review. Therefore, studies with weaker quality were given no less importance than findings from studies with greater quality. Nevertheless, most studies on the potential effects of dopamine on PA presented a 'weak' quality assessment. Furthermore, the studies included presented a variety of methods to assess both PA and dopamine, leading to difficulties and caution in the comparisons presented. Grey literature was not searched or included, and six studies were inaccessible. In addition, there was a lack of trials, indicating that larger representative trials are still warranted. Moreover, we found few studies investigating the effect of PA on dopamine and no studies investigating the effect of dopamine on PA in the long term, which also warrants further investigation. Finally, the present review did not focus on the different aspects of the dopamine system. Future research will have to focus on this issue and determine the detailed mechanisms of PA-related changes in the different roles of dopamine in the system.

\section{Conclusions}

Summarizing the prior empirical evidence on the reciprocal relationship between PA and dopamine, we observed robust findings concerning potential effects of PA on dopamine, which seem to be observable across a wide range of participant characteristics, a variety of PA characteristics, and a broad set of methods to analyse dopamine. By contrast, for potential effects of dopamine on PA, findings were mixed across studies, with only the study of neutral conditions (i.e., examining dopamine without exposure to drugs) able to demonstrate a coherent positive effect of dopamine on habitual PA measured by accelerometers. 
With respect to translating this research to clinical practice, it is appropriate to suggest that health professionals should encourage engagement in PA as a strategy to improve dopamine levels and possibly promote mental health. Furthermore, these findings reinforce the chain of thought suggesting that PA should be considered as an intervention strategy for improving mental health.

Author Contributions: A.M. and A.I. contributed to the conception and design of the study; were responsible for data collection, analysis, and interpretation; and were in charge of writing the manuscript. M.P. contributed to the collection of data, contributed to the analysis and interpretation of the data, and provided feedback on the drafts of this paper. P.M. contributed to the writing of the manuscript, interpretation of the data, and provided feedback on the drafts of this paper. A.O.W. contributed to the assessment of the quality of the studies and provided feedback on the drafts of this paper. G.F., É.R.G. and M.K. provided feedback on the drafts of this paper. All authors have read and agreed to the published version of the manuscript.

Funding: This work was supported by the Swiss National Centre of Competence in Research LIVES-Overcoming vulnerability: life course perspectives, granted by the Swiss National Science Foundation (grant number: 51NF40-185901). A.I. acknowledges support from the Swiss National Science Foundation (grant number: 10001C_189407).

Conflicts of Interest: All authors declare that they have no conflicts of interest.

\section{References}

1. Lin, T.-W.; Kuo, Y.-M. Exercise Benefits Brain Function: The Monoamine Connection. Brain Sci. 2013, 3, 39-53. [CrossRef] [PubMed]

2. Carlsson, A.; Lindqvist, M.; Magnusson, T. 3,4-Dihydroxyphenylalanine and 5-Hydroxytryptophan as Reserpine Antagonists. Nature 1957, 180, 1200. [CrossRef] [PubMed]

3. Harrington, K.; Augood, S.; Kingsbury, A.; Foster, O.; Emson, P. Dopamine transporter (DAT) and synaptic vesicle amine transporter (VMAT2) gene expression in the substantia nigra of control and Parkinson's disease. Br. Res. Mol. Brain Res. 1996, 36, 157-162. [CrossRef]

4. Luciana, M.; Collins, P.F.; A Depue, R. Opposing roles for dopamine and serotonin in the modulation of human spatial working memory functions. Cereb. Cortex (N. Y. 1991) 1998, 8, 218-226. [CrossRef]

5. Solinas, M.; Belujon, P.; Fernagut, P.O.; Jaber, M.; Thiriet, N. Dopamine and addiction: What have we learned from 40 years of research. J. Neural Transm. (Vienna) 2019, 126, 481-516. [CrossRef]

6. Klein, M.O.; Battagello, D.S.; Cardoso, A.R.; Hauser, D.N.; Bittencourt, J.C.; Correa, R.G. Dopamine: Functions, Signaling, and Association with Neurological Diseases. Cell. Mol. Neurobiol. 2019, 39, 31-59. [CrossRef]

7. Kim, Y.-S.; O'Sullivan, D.M.; Shin, S.-K. Can 24 weeks strength training reduce feelings of depression and increase neurotransmitter in elderly females? Exp. Gerontol. 2019, 115, 62-68. [CrossRef]

8. Freed, C.R.; Yamamoto, B.K. Regional brain dopamine metabolism: A marker for the speed, direction, and posture of moving animals. Science (N. Y.) 1985, 229, 62-65. [CrossRef]

9. Bäckman, L.; Nyberg, L.; Lindenberger, U.; Li, S.-C.; Farde, L. The correlative triad among aging, dopamine, and cognition: Current status and future prospects. Neurosci. Biobehav. Rev. 2006, 30, 791-807. [CrossRef]

10. Seidler, R.D.; Bernard, J.A.; Burutolu, T.B.; Fling, B.W.; Gordon, M.T.; Gwin, J.T.; Kwak, Y.; Lipps, D.B. Motor control and aging: Links to age-related brain structural, functional, and biochemical effects. Neurosci. Biobehav. Rev. 2010, 34, 721-733. [CrossRef]

11. Dohrn, I.-M.; Papenberg, G.; Winkler, E.; Welmer, A.-K. Impact of dopamine-related genetic variants on physical activity in old age-A cohort study. Int. J. Behav. Nutr. Phys. Act. 2020, 17, 1-8. [CrossRef] [PubMed]

12. Flack, K.; Pankey, C.; Ufholz, K.; Johnson, L.; Roemmich, J.N. Genetic variations in the dopamine reward system influence exercise reinforcement and tolerance for exercise intensity. Behav. Brain Res. 2019, 375, 112148. [CrossRef]

13. Schultz, W. Dopamine signals for reward value and risk: Basic and recent data. Behav. Brain Funct. BBF 2010, 6, 24. [CrossRef]

14. Ott, T.; Nieder, A. Dopamine and Cognitive Control in Prefrontal Cortex. Trends Cogn. Sci. 2019, 23, 213-234. [CrossRef] [PubMed]

15. Audiffren, M.; André, N. The exercise-cognition relationship: A virtuous circle. J. Sport Health Sci. 2019, 8, 339-347. [CrossRef]

16. Bernheimer, H.; Hornykiewicz, O. Decreased homovanillic acid concentration in the brain in parkinsonian subjects as an expression of a disorder of central dopamine metabolism. Klin. Wochenschr. 1965, 43, 711-715. [CrossRef]

17. Meeusen, R.; De Meirleir, K. Exercise and Brain Neurotransmission. Sports Med. 1995, 20, 160-188. [CrossRef] [PubMed]

18. Lista, I.; Sorrentino, G. Biological Mechanisms of Physical Activity in Preventing Cognitive Decline. Cell. Mol. Neurobiol. 2009, 30, 493-503. [CrossRef]

19. Dishman, R.; Renner, K.; Youngstedt, S.; Reigle, T.; Bunnell, B.; Burke, K.; Yoo, H.; Mougey, E.; Meyerhoff, J. Activity Wheel Running Reduces Escape Latency and Alters Brain Monoamine Levels After Footshock. Brain Res. Bull. 1997, 42, 399-406. [CrossRef] 
20. Meeusen, R.; Piacentini, M. Exercise and Neurotransmission: A Window to the Future? Eur. J. Sport Sci. 2001, 1, 1-12. [CrossRef]

21. Juarez, E.J.; Samanez-Larkin, G.R. Exercise, Dopamine, and Cognition in Older Age. Trends Cogn. Sci. 2019, 23, 986-988. [CrossRef] [PubMed]

22. Kandola, A.; Vancampfort, D.; Herring, M.; Rebar, A.; Hallgren, M.; Firth, J.; Stubbs, B. Moving to Beat Anxiety: Epidemiology and Therapeutic Issues with Physical Activity for Anxiety. Curr. Psychiatry Rep. 2018, 20, 1-9. [CrossRef]

23. Bell, S.L.; Audrey, S.; Gunnell, D.; Cooper, A.; Campbell, R. The relationship between physical activity, mental wellbeing and symptoms of mental health disorder in adolescents: A cohort study. Int. J. Behav. Nutr. Phys. Act. 2019, 16, 1-12. [CrossRef] [PubMed]

24. Cooney, G.M.; Dwan, K.; Greig, C.A.; Lawlor, D.A.; Rimer, J.; Waugh, F.R.; McMurdo, M.; Mead, G.E. Exercise for depression. Cochrane Database Syst. Rev. 2013, 9, CD004366. [CrossRef]

25. Wu, S.-Y.; Wang, T.-F.; Yu, L.; Jen, C.J.; Chuang, J.-I.; Wu, F.-S.; Wu, C.-W.; Kuo, Y.-M. Running exercise protects the substantia nigra dopaminergic neurons against inflammation-induced degeneration via the activation of BDNF signaling pathway. Brain, Behav. Immun. 2011, 25, 135-146. [CrossRef]

26. Gerecke, K.M.; Jiao, Y.; Pani, A.; Pagala, V.; Smeyne, R.J. Exercise protects against MPTP-induced neurotoxicity in mice. Brain Res. 2010, 1341, 72-83. [CrossRef]

27. Xu, Q.; Park, Y.; Huang, X.; Hollenbeck, A.; Blair, A.; Schatzkin, A.; Chen, H. Physical activities and future risk of Parkinson disease. Neurology 2010, 75, 341-348. [CrossRef]

28. Hoffmann, P.; Elam, M.; Thorén, P.; Hjorth, S. Effects of long-lasting voluntary running on the cerebral levels of dopamine, serotonin and their metabolites in the spontaneously hypertensive rat. Life Sci. 1994, 54, 855-861. [CrossRef]

29. Macrae, P.G.; Spirduso, W.W.; Walters, J.; Farrar, R.P.; Wilcox, R.E. Endurance training effects on striatal D2 dopamine receptor binding and striatal dopamine metabolites in presenescent older rats. Psychopharmacology 1987, 92, 236-240. [CrossRef]

30. Renoir, T.; Chevarin, C.; Lanfumey-Mongredien, L.; Hannan, A.J. Effect of enhanced voluntary physical exercise on brain levels of monoamines in Huntington disease mice. PLoS Curr. 2011, 3, RRN1281. [CrossRef]

31. Foley, T.E.; Fleshner, M. Neuroplasticity of Dopamine Circuits After Exercise: Implications for Central Fatigue. Neuromol. Med. 2008, 10, 67-80. [CrossRef] [PubMed]

32. Cordeiro, L.M.D.S.; Rabelo, P.; Moraes, M.; Teixeira-Coelho, F.; Coimbra, C.; Wanner, S.; Soares, D. Physical exercise-induced fatigue: The role of serotonergic and dopaminergic systems. Braz. J. Med Biol. Res. 2017, 50, e6432. [CrossRef] [PubMed]

33. Klass, M.; Roelands, B.; Lévénez, M.; Fontenelle, V.; Pattyn, N.; Meeusen, R.; Duchateau, J. Effects of Noradrenaline and Dopamine on Supraspinal Fatigue in Well-Trained Men. Med. Sci. Sports Exerc. 2012, 44, 2299-2308. [CrossRef] [PubMed]

34. Avraham, Y.; Hao, S.; Mendelson, S.; Berry, E.M. Tyrosine improves appetite, cognition, and exercise tolerance in activity anorexia. Med. Sci. Sports Exerc. 2001, 33, 2104-2110. [CrossRef]

35. I Kalinski, M.; E Dluzen, D.; Stadulis, R. Methamphetamine produces subsequent reductions in running time to exhaustion in mice. Brain Res. 2001, 921, 160-164. [CrossRef]

36. Bracken, M.E.; Bracken, D.R.; Winder, W.W.; Conlee, R.K. Effect of various doses of cocaine on endurance capacity in rats. J. Appl. Physiol. (Bethesda Md. 1985) 1989, 66, 377-383. [CrossRef]

37. Burgess, M.L.; Davis, J.M.; Borg, T.K.; Buggy, J. Intracranial self-stimulation motivates treadmill running in rats. J. Appl. Physiol. (Bethesda Md. 1985) 1991, 71, 1593-1597. [CrossRef] [PubMed]

38. Carneiro, L.S.F.; Mota, M.P.; Vieira-Coelho, M.A.; Alves, R.C.; Fonseca, A.M.; Vasconcelos-Raposo, J. Monoamines and cortisol as potential mediators of the relationship between exercise and depressive symptoms. Eur. Arch. Psychiatry Clin. Neurosci. 2017, 267, 117-121. [CrossRef]

39. Fornaro, M.; Solmi, M.; Veronese, N.; De Berardis, D.; Buonaguro, E.F.; Tomasetti, C.; Perna, G.; Preti, A.; Carta, M.G. The burden of mood-disorder/cerebrovascular disease comorbidity: Essential neurobiology, psychopharmacology, and physical activity interventions. Int. Rev. Psychiatry 2017, 29, 425-435. [CrossRef]

40. Moher, D.; Liberati, A.; Tetzlaff, J.; Altman, D.G. Preferred reporting items for systematic reviews and meta-analyses: The PRISMA statement. BMJ 2009, 339, 332-336. [CrossRef] [PubMed]

41. Armijo-Olivo, S.; Stiles, C.R.; Hagen, N.A.; Biondo, P.D.; Cummings, G.G. Assessment of study quality for systematic reviews: A comparison of the Cochrane Collaboration Risk of Bias Tool and the Effective Public Health Practice Project Quality Assessment Tool: Methodological research. J. Eval. Clin. Pr. 2010, 18, 12-18. [CrossRef]

42. Sacheli, M.A.S.; Neva, J.L.; Lakhani, B.; Msc, D.K.M.; Vafai, N.; Shahinfard, E.; English, C.; McCormick, S.; Dinelle, K.; Rn, N.N.; et al. Exercise increases caudate dopamine release and ventral striatal activation in Parkinson's disease. Mov. Disord. Off. J. Mov. Disord. Soc. 2019, 34, 1891-1900. [CrossRef]

43. Janssen, C.; Beloka, S.; Kayembe, P.; DeBoeck, G.; Adamopoulos, D.; Naeije, R.; Van De Borne, P. Decreased ventilatory response to exercise by dopamine-induced inhibition of peripheral chemosensitivity. Respir. Physiol. Neurobiol. 2009, 168, 250-253. [CrossRef]

44. Rosso, A.L.; Metti, A.L.; Glynn, N.W.; Boudreau, R.M.; Rejeski, W.J.; Bohnen, N.; Chen, H.; Johannsen, N.M.; King, A.C.; Manini, T.M.; et al. Dopamine-Related Genotypes and Physical Activity Change During an Intervention: The Lifestyle Interventions and Independence for Elders Study. J. Am. Geriatr. Soc. 2018, 66, 1172-1179. [CrossRef]

45. Wooten, G.F.; Cardon, P.V. Plasma dopamine-Hydroxylase activity. Elevation in man during cold pressor test and exercise. Arch Neurol. 1973, 28, 103-106. [CrossRef] 
46. Péronnet, F.; Cléroux, J.; Perrault, H.; Thibault, G.; Cousineau, D.; De Champlain, J.; Guilland, J.-C.; Klepping, J. Plasma norepinephrine, epinephrine, and dopamine ??-hydroxylase activity during exercise in man. Med. Sci. Sports Exerc. 1985, 17, 683-688. [CrossRef]

47. Hartling, O.J.; Kelbaek, H.; Gjørup, T.; Nielsen, M.D.; Trap-Jensen, J.; Kelbæk, H. Plasma concentrations of adrenaline, noradrenaline and dopamine during forearm dynamic exercise. Clin. Physiol. (Oxf. Engl.) 1989, 9, 399-404. [CrossRef] [PubMed]

48. Kinoshita, A.; Koga, M.; Matsusaki, M.; Ikeda, M.; Tanaka, H.; Shindo, M.; Arakawa, K. Changes of Dopamine and Atrial Natriuretic Factor by Mild Exercise for Hypertensives. Clin. Exp. Hypertens. Part A Theory Pr. 1991, 13, 1275-1290. [CrossRef] [PubMed]

49. Nozaki, T.; Sugiyama, K.; Yagi, S.; Yoshikawa, E.; Kanno, T.; Asakawa, T.; Ito, T.; Terada, T.; Namba, H.; Ouchi, Y. Effect of Subthalamic Nucleus Stimulation during Exercise on the Mesolimbocortical Dopaminergic Region in Parkinson'S Disease: A Positron Emission Tomography Study. J. Cereb. Blood Flow Metab. Off. J. Int. Soc. Cereb. Blood Flow Metab. 2012, 33, 415-421. [CrossRef]

50. Robertson, C.L.; Ishibashi, K.; Chudzynski, J.; Mooney, L.J.; A Rawson, R.; A Dolezal, B.; Cooper, C.B.; Brown, A.K.; A Mandelkern, M.; London, E.D. Effect of Exercise Training on Striatal Dopamine D2/D3 Receptors in Methamphetamine Users during Behavioral Treatment. Neuropsychopharmacol. Off. Publ. Am. Coll. Neuropsychopharmacol. 2015, 41, 1629-1636. [CrossRef] [PubMed]

51. Maskin, C.S.; Kugler, J.; Sonnenblick, E.H.; LeJemtel, T.H. Acute inotropic stimulation with dopamine in severe congestive heart failure: Beneficial hemodynamic effect at rest but not during maximal exercise. Am. J. Cardiol. 1983, 52, 1028-1032. [CrossRef]

52. Boetger, C.L.; Ward, D.S. Effect of dopamine on transient ventilatory response to exercise. J. Appl. Physiol. (Bethesda Md. 1985) 1986, 61, 2102-2107. [CrossRef] [PubMed]

53. Lundby, C.; Møller, P.; Kanstrup, I.L.; Olsen, N.V. Heart rate response to hypoxic exercise: Role of dopamine D2-receptors and effect of oxygen supplementation. Clin. Sci. (Lond. Engl. 1979) 2001, 101, 377-383. [CrossRef]

54. Watson, P.; Hasegawa, H.; Roelands, B.; Piacentini, M.F.; Looverie, R.; Meeusen, R. Acute dopamine/noradrenaline reuptake inhibition enhances human exercise performance in warm, but not temperate conditions. J. Physiol. 2005, 565, 873-883. [CrossRef] [PubMed]

55. Tedjasaputra, V.; Bryan, T.L.; Van Diepen, S.; Moore, L.E.; Bouwsema, M.M.; Welsh, R.C.; Petersen, S.R.; Stickland, M.K. Dopamine receptor blockade improves pulmonary gas exchange but decreases exercise performance in healthy humans. J. Physiol. 2015, 593, 3147-3157. [CrossRef] [PubMed]

56. Connell, C.J.W.; Thompson, B.; Turuwhenua, J.; Srzich, A.; Gant, N. Effects of Dopamine and Norepinephrine on Exercise-induced Oculomotor Fatigue. Med. Sci. Sports Exerc. 2017, 49, 1778-1788. [CrossRef]

57. USDHHS. Physical Activity Guidelines Advisory Committee Scientific Report; U.S. Department of Health and Human Services: Washington, DC, USA, 2018.

58. Roig-Coll, F.; Castells-Sánchez, A.; Lamonja-Vicente, N.; Torán-Monserrat, P.; Pera, G.; García-Molina, A.; Tormos, J.M.; MonteroAlía, P.; Alzamora, M.T.; Dacosta-Aguayo, R.; et al. Effects of Aerobic Exercise, Cognitive and Combined Training on Cognition in Physically Inactive Healthy Late-Middle-Aged Adults: The Projecte Moviment Randomized Controlled Trial. Front. Aging Neurosci. 2020, 12, 590168. [CrossRef] [PubMed]

59. Engeroff, T.; Vogt, L.; Fleckenstein, J.; Füzéki, E.; Matura, S.; Pilatus, U.; Schwarz, S.; Deichmann, R.; Hellweg, R.; Pantel, J.; et al. Lifespan leisure physical activity profile, brain plasticity and cognitive function in old age. Aging Ment. Health 2018, 23, 811-818. [CrossRef]

60. Basso, J.C.; Suzuki, W.A. The Effects of Acute Exercise on Mood, Cognition, Neurophysiology, and Neurochemical Pathways: A Review. Brain Plast. 2017, 2, 127-152. [CrossRef]

61. Inoue, D.S.; Monteiro, P.A.; Gerosa-Neto, J.; Santana, P.R.; Peres, F.P.; Edwards, K.M.; Lira, F.S. Acute increases in brain-derived neurotrophic factor following high or moderate-intensity exercise is accompanied with better cognition performance in obese adults. Sci. Rep. 2020, 10, 1-8. [CrossRef]

62. Marques, A.; Bordado, J.; Peralta, M.; Gouveia, E.R.; Tesler, R.; Demetriou, Y.; Baya, D.G. Cross-sectional and prospective relationship between physical activity and depression symptoms. Sci. Rep. 2020, 10, 1-8. [CrossRef] [PubMed]

63. Marques, A.; de Matos, M.G.; Henriques-Neto, D.; Peralta, M.; Élvio, R.G.; Tesler, R.; Martins, J.; Gomez-Baya, D. Grip Strength and Depression Symptoms Among Middle-Age and Older Adults. Mayo Clin. Proc. 2020, 95, 2134-2143. [CrossRef] [PubMed]

64. Marques, A.; Peralta, M.; Élvio, R.G.; Martins, J.; Sarmento, H.; Gomez-Baya, D. Leisure-time physical activity is negatively associated with depression symptoms independently of the socioeconomic status. Eur. J. Sport Sci. 2020, 20, 1268-1276. [CrossRef] [PubMed]

65. Hallgren, M.; Stubbs, B.; Vancampfort, D.; Lundin, A.; Jääkallio, P.; Forsell, Y. Treatment Guidelines for Depression: Greater Emphasis on Physical Activity is Needed. Eur. Psychiatry J. Assoc. Eur. Psychiatr. 2016, 40, 1-3. [CrossRef]

66. Schuch, F.B.; Deslandes, A.; Stubbs, B.; Gosmann, N.P.; da Silva, C.T.B.; Fleck, M.P.D.A. Neurobiological effects of exercise on major depressive disorder: A systematic review. Neurosci. Biobehav. Rev. 2016, 61, 1-11. [CrossRef] [PubMed]

67. Correa, M.; Pardo, M.; Bayarri, P.; López-Cruz, L.; Miguel, N.S.; Valverde, O.; Ledent, C.; Salamone, J.D. Choosing voluntary exercise over sucrose consumption depends upon dopamine transmission: Effects of haloperidol in wild type and adenosine A2AKO mice. Psychopharmacology 2015, 233, 393-404. [CrossRef]

68. Smythies, J. Section II. The Dopamine System. Int. Rev. Neurobiol. 2005, 64, 123-172. [CrossRef] 